\title{
POLICIES FOR PORTUGUESE AND SPANISH: the world's second publication language in web of science
}

\author{
POLÍTICAS PARA PORTUGUÊS E ESPANHOL: \\ a segunda língua de publicação do mundo em teia da ciência
}

Anabela Gradim 1

Valeriano Piñeiro-Naval

\begin{abstract}
The article determines the profile and evolution of publication languages in Web of Science since the 1960's, exploring its consequences to academic publishing and scientific communication inter pares. Findings show that Portuguese and Spanish (Iberian languages), absent in the early sixties, are now the second publication language in Web of Science, while traditional influential publication languages as German, French and Russian have decreased their output, and English remains the dominant idiom. The research collected data on all documents published annually in Web of Science, Science Citation Index and Social Sciences Citation Index between 1960 and 2015, resulting in a database that analyses 51 million scientific items. Discovering Iberian languages are the second publication idiom in Web of Science, the article discusses their high status in elite academic publishing, and its potential and consequences in terms of scientific and economic prestige, language policy, and possible incentives to balance English language hegemony. Especially in science publishing, idiom dominance tends to be presented as a neutral feature - an objectification of language envisaged as a natural means destined to a transparent communication. Challenging such naturalization, the article examines multilingualism in science publication as an asset that could be valued in determining science and language policies, contributing to the ongoing debate on language diversity in science.
\end{abstract}

Keywords: Databases. Documents. Language of science. Academic publishing. Language policy.

\section{RESUMO}

0 artigo determina o perfil e a evolução das linguagens de publicação na Web of Science desde a década de 1960, explorando suas consequências para a publicação acadêmica e a comunicação científica inter pares. As descobertas mostram que o português e 0 espanhol (idiomas ibéricos), ausentes no início dos anos sessenta, são agora o segundo idioma de publicação do Web of Science, enquanto os tradicionais idiomas de publicação como alemão, francês e russo diminuíram sua produção, e o inglês continua sendo o idioma dominante. A pesquisa coletou dados sobre todos os documentos publicados anualmente no Web of Science, no Science Citation Index e no Social Sciences Citation Index entre 1960 e 2015, resultando em um banco de dados que analisa 51 milhões de itens científicos. Descobrir as línguas ibéricas é 0 segundo idioma de publicação em Web of Science, 0 artigo discute seu alto status na publicação acadêmica de elite e suas potencialidades e consequências em termos de prestígio científico e econômico, política lingüística e possíveis incentivos para equilibrar a hegemonia da língua inglesa. Especialmente na publicação científica, a dominação idiomática tende a ser apresentada como uma característica neutra - uma objetivação da linguagem imaginada como um meio natural destinado a uma comunicação transparente. Desafiando essa naturalização, 0 artigo examina 0 multilinguismo na publicação científica como um ativo que poderia ser valorizado na determinação de políticas científicas e lingüísticas, contribuindo para o debate em curso sobre diversidade linguística na ciência.

Palavras-chave: Bancos de dados. Documentos. Linguagem da ciência. Publicação acadêmica. Política de Idiomas.

Artigo recebido em 15/02/2018 e aceito para publicação em 13/05/2019.

1 Doutora em Ciências da Comunicação pela Universidade da Beira Interior, Portugal. Pesquisadora do Laboratório de Comunicação Online - LabCom da Universidade da Beira Interior, Portugal. Coordenadora do Doutorado em Ciências da Comunicação da Universidade da Beira Interior, Portugal. E-mail: anabela.gradim@labcom.ubi.pt.

2 Doutor em Ciências da Comunicação pela Universidade da Beira Interior, Portugal. Pesquisador do Laboratório de Comunicação Online - LabCom da Universidade da Beira Interior, Portugal. E-mail: vale.naval@labcom.ubi.pt. 


\section{INTRODUCTION}

Despite the absence of an academic publishing policy favoring national languages and multilingualism, and instead, the clear enforcement for publishing in Anglophone indexed outlets in the Iberian peninsula (GRADIM; MORAIS, 2016b), Portuguese and Spanish languages have been consistently growing in Thomson Web of Science (former ISI) databases, replacing traditional representative languages such as German, Russian, and French. In the last few years, despite a clearer English dominance, Iberian languages are the second publication idiom in the database, following very similar growth patterns in Science Citation Index and Social Sciences Citation Index.

Founded in 1955 by Eugene Garfield, ISI - Institute for Scientific Information, responded to the age-old challenge of communicating and classifying knowledge and science. Garfield developed the concept of citation index, and created the SCI - Science Citation Index, based on a simple principle: the number of references a journal received in the past two years, divided by the articles it has published within the same time frame, is a measure of its influence and constitutes its Impact Factor (IF). The patent of the IF algorithm turned more complex over the years, delivering Science Citation Index (SCI), Social Sciences Citation Index (SSCI), Arts and Humanities Citation Index (AHCI), and being generally recognized the IF accounts for the relevance and influence of scientific journals (GARFIELD, 1979; 1995).

Citation indexing is a natural or automatic system of classification: the material to be classified orders itself through its conceptual links (GARFIELD et al., 1988). Garfield's method classifies knowledge objectively from its internal relations structure, and this order is somehow a measure of the impact or influence of such knowledge, much in the same way Google's Pagerank algorithm determines relevance for search results (PAGE et al., 1999).

In 1992 Thomson Reuters acquired ISI, changing its name to Web of Science (WoS). The number of published items grows at an impressive rate every year. The company's interest is to select the best science - meaning the most popular and influent - and the information it provides constitutes an important tool for scientists and librarians alike (TESTA, 2009). According to the Master Journal List of Clarivate Analytics, by the end of 2017 SCIE comprised 8955 journals, and SSCI covered 3286 journals. ${ }^{3}$

3 http://ip-science.thomsonreuters.com/mjl/ (last viewed in 2017-12-12) 
Due to its importance in the core scientific literature, and also due to the fact it collects 56 years of data, we chose to study the evolution of science publishing languages through SCIE and SSCI. The findings show an ever-growing dominance of the English language, the decline of former relevant European languages, and from 2009 onwards a significant raise of Iberian languages: Spanish and Portuguese, which together are now the second most published languages in Web of Science.

\section{LANGUAGES WE LIVE BY}

"The Portuguese language is pluricontinental and polycentric. While being the same language, it is spoken and written in different forms, corresponding to different histories, heritage, linguistic neighbourhoods, grammatical and pragmatic structures, cultural references and social conduct. So it includes many variants, being a dynamic and multiform reality" (RET0 et al., 2016, p. 15).

Portuguese is the official language of eight countries, exceeding 275 million speakers who represent $3,7 \%$ of the world population, and is a global language which, "rather than confined to a single region, is spread over all continents" being presently "among the five most widely spoken languages of the entire world, and also among the five most used by internet users" (RET0 et al., 2016, p. 9). As the first most spoken language on the southern hemisphere, in 2016-17 gathered 200 thousand foreign students in more than seventy countries, with an estimated speakers growth up to 390 millions by midcentury, and 487 millions by the end of the century (idem).

Spanish is an even bigger linguistic superpower. It is the official language of 21 countries, the second world maternal language by number of speakers, after Mandarin Chinese, and also globally the second most spoken language, if we count native and non-native speakers. These numbers add up to 472 million native speakers, and 567 million "potential speakers". In 2016 7,8\% of the world's population was Spanish-speaking, and this percentage is estimated to remain stable until 2050 (754 million people), accompanying the world's population growht, while native speakers of English and Chinese are bound to decline due to demographics (Vítores, 2016).

Adding Spanish and Portuguese as Iberian languages, spoken in a peninsula where their linguistic differentiation emerged slowly across the centuries might reinforce both their strength, and recall their similarities. "Together, they form the largest Indo-European linguistic bloc, currently with 700 million native speakers. There is an objective base for such proximity, which is the inter-understanding among their speakers [...] Even without formal learning of the other language, Spanish and Portuguese 
speakers manage to communicate" (RETO et al., 2016, p. 15). The pervasiveness of both languages in the two hemispheres "suggests a field of action and influence which challenges the traditional divisions between north and south" (idem).

English has 375 million native speakers worldwide, and a total of 1500 millions native and nonnative, making it the most important contemporary world language, right before Chinese, with 1110 million speakers. Due to its prestige and omnipresence, it is commonly envisaged as the global language of science, a lingua franca for scientific communication as Latin once was (GARFIELD, 1967; CRYSTAL, 2003; HAMEL, 2007; MENEGHINI E PACKER, 2007; GRADIM; MORAIS, 2016a). The effectiveness and advantages of that role are extensive (VAN WEIJEN, 2012), but not neutral (FOUCAULT, 1980; BOURDIEU, 1982; 1991; FOUCAULT, 2010; MARTINS, 2012; 2014), and though hard to conceive, its importance, which follows the rise of global British and American military and economic power, might not be perpetual (OSTLER, 2010).

Recognizing the advantages of an instrumental language for communication, our discussion of the results intends to show that being advantageous doesn't mean being neutral or unbiased. Language is a system of power, defined as "the structural capacity of a social actor to impose its will over other social actor(s)" (CASTELLS, 2007, p. 239); and therefore to protect linguistic diversity is also to protect the quality of science and the diversity, representativeness and prestige of the languages in which it is produced. Multilingualism, notably in Social Sciences, should be encouraged, and the Iberian countries, former imperial powers whose languages are spoken in several continents, have been assuming neutral or harmful policies towards this objective (GRADIM et al., 2014).

\section{DATA COLLECTION AND METHODOLOGIES}

The survey collected data on all items published annually in Web of Science, Science Citation Index and Social Sciences Citation Index between 1960 and 2015, categorizing them by language of publication. The result is a database that analyses 51 million scientific documents, 7 million and 420 thousand belonging to the SSCI, and 43 million and 926 thousand belonging to the $\mathrm{SCl}$.

Over the five and a half decades that the study covers dozens of languages were represented in WoS, some insignificantly: publishing a single item would make the language enter into the data 
collected. To select the Languages to study, considering their representativeness, it was decided to comprise the first eight to appear in the 60's, and the first eight that appeared in the same list in 2015, resulting in a sample of 12 languages, whose profile was studied in detail, selected according to the following table:

Table 1 - Sample of languages considered

\begin{tabular}{|c|c|c|c|}
\hline \multicolumn{2}{|c|}{ SCI-Science Citation Index } & \multicolumn{2}{|c|}{ SSCI-Social Sciences Citation Index } \\
\hline 1960 & 2015 & 1960 & 2015 \\
\hline 1. English & 1. English & 1. English & 1. English \\
\hline 2. Russiam & 2. German & 2. French & 2. German \\
\hline 3. German & 3. Spanish & 3. German & 3. Spanish \\
\hline 4. French & 4. Chinese & 4. Russian & 4. French \\
\hline 5. Dutch & 5. French & 5. Dutch & 5. Portuguese \\
\hline 6. Spanish & 6. Portuguese & 6. Spanish & 6. Russian \\
\hline 7. Japanese & 7. Polish & 7. Italian & 7. Czech \\
\hline 8. Italian & 8. Japanese & 8. Afrikaans & 8. Italian \\
\hline $\begin{array}{l}100 \% \text { coverage in } \\
\text { the years considered }\end{array}$ & $\begin{array}{l}99.8 \% \text { coverage in } \\
\text { the year considered }\end{array}$ & $\begin{array}{l}100 \% \text { coverage in } \\
\text { the year considered }\end{array}$ & $\begin{array}{l}99.7 \% \text { coverage in } \\
\text { the year considered }\end{array}$ \\
\hline
\end{tabular}

Source: own

Drawing the cut line in the eighth most popular language accounts for more than $99 \%$ of WoS' scientific publication in the years considered, meaning that, despite the quantity, the values of the excluded languages are statistically insignificant.

\section{RESULTS}

The panel presented collects three temporal charts: one with the evolution of scientific documents included in Science Citation Index Expanded (SCIE); the second showing the evolution of published items in Social Sciences Citation Index (SSCI), and a third one bringing together both rankings, according to their publication language: 
Figure 1- Panel with the temporal evolution of the scientific documents according to their languages of publication (except English)

Temporal Evolution SCI Scientific Papers:

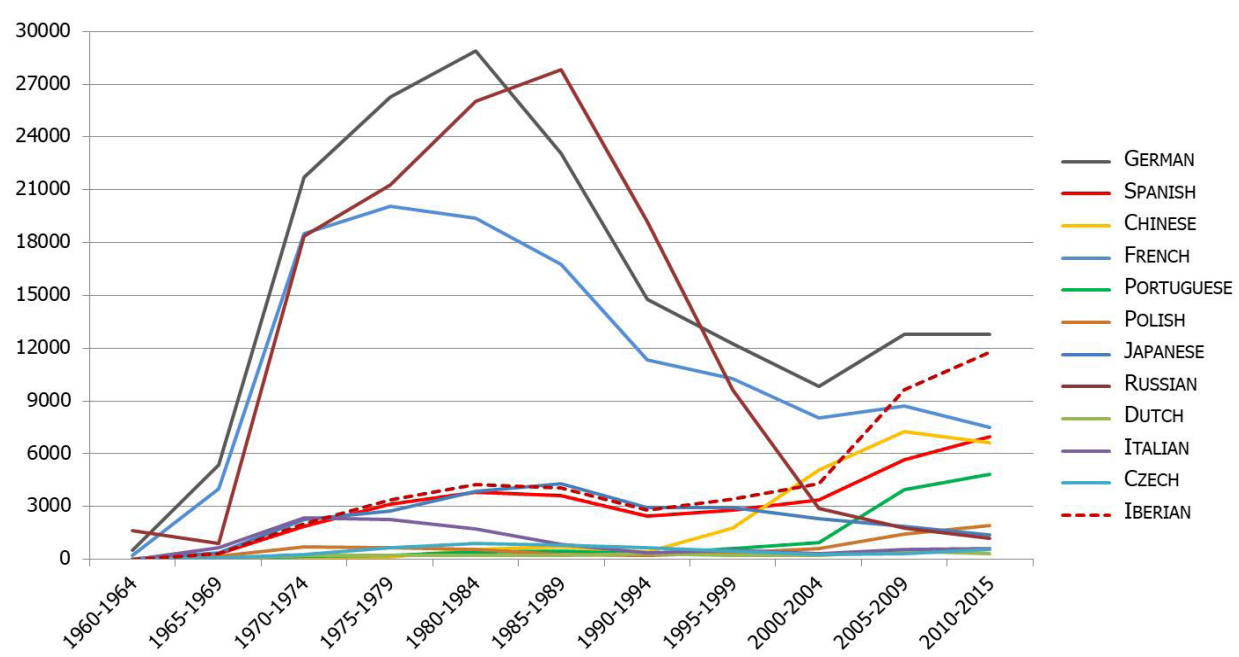

Temporal Evolution SSCI Scientific Papers:

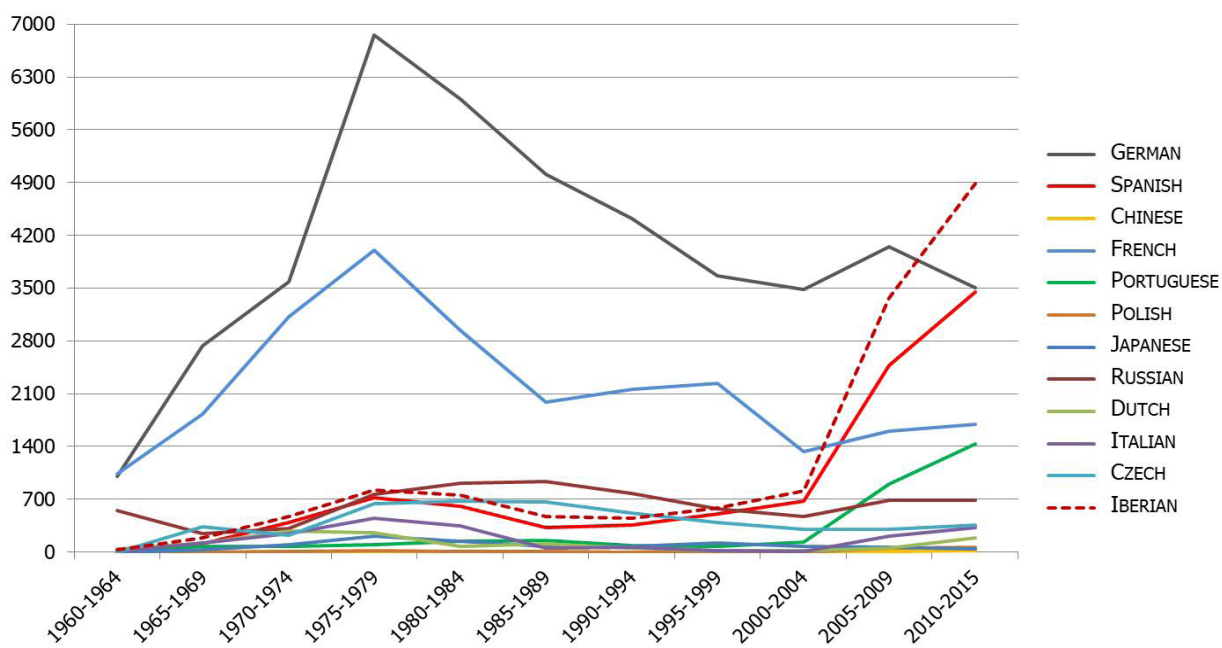

Temporal Evolution Total Scientific Papers:

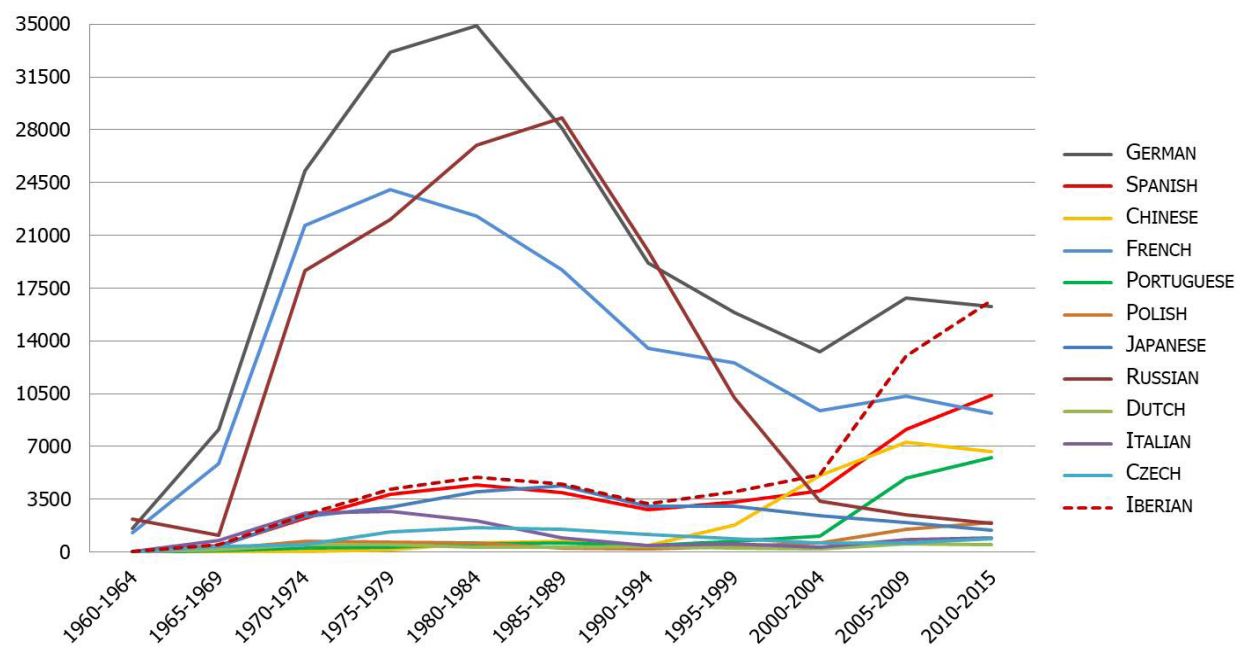

Source: own 
As the charts show, Iberian languages have experienced a remarkable increase since the luster of 2005-2010. Moreover, from 2009 onwards we see a definite turning point until - for the first time since 1960 - it grows into the second language of knowledge diffusion, surpassing German and other important languages, traditionally ahead in both databases.

In general terms, international scientific production in exact sciences (SCI) and in social and human sciences (SSCI) have followed, since the 1960s, a parallel and highly correlated growth $[r(726)$ $=0.98 ; p<0.001]$. A finer analysis on our data shows that as Iberian languages' publication output in SCIE increased, it also augmented in SSCI.

In terms of languages, and taking into account the sample for the total period studied (19602015, thus 56 years and 51 million items), the differences between the annual mean of documents published in the different languages are statistically significant $\left[F_{\text {Annual Publications } X \text { Language }}(12,715)=149.13\right.$; $\left.p<0.001 ; \eta^{2}=0.715\right]$. Dunnett's post-hoc T3 test showed that the greatest differences were found between English and other languages $(p<0.001)$, with the Anglo-Saxon language showing the highest annual average of bibliographic references $(M=856944 ; S D=521716)$. See table 2 for the detailed breakdown of average documents for each language:

Table 2 - Average annual scientific publications (1960-2015) for each language (ANOVA)

\begin{tabular}{lccc}
\hline IDIOMS & M & SD & N \\
\hline English & 856944 & 521716 & 56 \\
German & 19274 & 10465 & 56 \\
French & 13451 & 7429 & 56 \\
Russian & 12319 & 10881 & 56 \\
Iberian & 5544 & 5447 & 56 \\
Spanish & 4078 & 3225 & 56 \\
Japanese & 2347 & 1367 & 56 \\
Chinese & 2143 & 2801 & 56 \\
Portuguese & 1465 & 2337 & 56 \\
Italian & 1106 & 982 & 56 \\
Czech & 862 & 506 & 56 \\
Polish & 672 & 670 & 56 \\
Dutch & 342 & 176 & 56 \\
\hline TOTAL & 70811 & 268741 & 728 \\
\hline$F_{\text {Annual Publications } \times \text { Language }}$ & & & \\
$(12,715)=149.13 ;$ & & & \\
$p<0.001 ; \eta^{2}=$ & & & \\
0.715 & & &
\end{tabular}

Source: own 
This hegemonic situation on the part of English also applies to the most recent years, that is to say, as of 2009. The following table shows the absolute and percentage data represented by each of the 12 selected languages in the context of international scientific production. We added to these the data related to the Iberian languages, which result from the sum of Spanish and Portuguese, and have done so in the $\mathrm{SCI}, \mathrm{SSCl}$ or the total aggregate ranking:

Table 3 - Frequencies and percentages of scientific documents (SCI, SSCI and total aggregate) in each of the languages, including Iberian, from 2009 to 2015.

\begin{tabular}{lcccccc}
\hline IDIOMS & \multicolumn{2}{c}{ SCI } & \multicolumn{3}{c}{ SSCI } & \multicolumn{2}{c}{ TOTAL } \\
\cline { 2 - 6 }$N$ & $\%$ & $N$ & $\%$ & $N$ & $\%$ & \\
\hline English & 11345167 & 96.52 & 1749228 & 93.56 & 13094395 & 96.12 \\
Iberian & 85863 & 0.73 & 35484 & 1.89 & 121347 & 0.89 \\
German & 90929 & 0.77 & 25051 & 1.34 & 115980 & 0.85 \\
Spanish & 50113 & 0.42 & 25121 & 1.34 & 75234 & 0.55 \\
French & 54484 & 0.46 & 12117 & 0.64 & 66601 & 0.48 \\
Chinese & 47380 & 0.40 & 120 & 0.006 & 47500 & 0.34 \\
Portuguese & 35750 & 0.30 & 10363 & 0.55 & 46113 & 0.33 \\
Polish & 13660 & 0.11 & 515 & 0.02 & 14175 & 0.10 \\
Russian & 8623 & 0.07 & 5021 & 0.26 & 13644 & 0.10 \\
Japanese & 10134 & 0.08 & 340 & 0.01 & 10474 & 0.07 \\
Italian & 4586 & 0.04 & 2314 & 0.12 & 6900 & 0.05 \\
Czech & 3759 & 0.03 & 2534 & 0.13 & 6293 & 0.04 \\
Dutch & 2505 & 0.02 & 1254 & 0.06 & 3759 & 0.03 \\
\hline TOTAL & & & & & \\
& 11752953 & & 1869462 & 99.92 & 13622415 & 99.95 \\
& 99.95 & & & & \\
\hline
\end{tabular}

Source: own

If we dwell on the data contained in Table 3, we observe that English continues to represent, undoubtedly, the predominant language in the international scientific production as a whole $\left[\chi^{2}(12)=\right.$ $86.04 ; p<0.001$ ], being used in the writing of $96.12 \%$ of the total documents. The data are very similar whether we focus exclusively on one or the other of the two rankings: in the $\mathrm{SCI}$ it represents $96.52 \%$ $\left[x^{2}(12)=86.38 ; p<0.001\right]$, while in the SSCI it decreases slightly to $93.56 \%\left[x^{2}(12)=87.11 ; p<\right.$ $0.001]$. 
Regarding Iberian languages, and even though German traditionally has surpassed it $t(110)$ $=8.70 ; p<0.001 ; d=1.65]$, this trend has changed in recent years. In fact, since 2009, there are no significant differences between the two $[U=0.575 ; p=0.565]$. Moreover, at the percentage level, Iberian languages have reached the second position in the total ranking of publications (see table 3 ). To reinforce these findings, if we consider the SSCI classification, the differences in favor of the Iberian languages with respect to the German language are statistically significant $[U=3.13 ; p<0.002]$.

On the other hand, where there are significant differences at the general level (ie, in the aggregate of the two rankings) it is between the Iberian languages and all the others $[U=3.13 ; p<0.002]$, highlighting the overtaking that Portuguese and Spanish have played in relation to French and Russian (historically more employed) or Chinese, the most spoken language in the world at the native level.

\section{FINDINGS AND DISCUSSION}

Recent studies have focused on the relationship between language and the political and material conditions of global neoliberal capitalism (RICENTO, 2000; JOSEPH, 2006; PHILLIPSON, 2009; FLORES; CHAPARR0, 2017), the legacy of colonialism in English language hegemony (PENNYCOOK, 2000; 2017) and the "insurmountable problems facing periphery scholars in representing their knowledge in scholarly fora", noticing the academic publishing industry serves to establish and maintain western intellectual hegemony in a global scale (CANAGARAJAH, 2002).

Scientific capitalism, with its ranking and evaluation devices, language policing, and close knit Anglophone-centric publishing industry is a system that has been delivering unsurpassed scientific and technological progress over the last decades, generally improving living conditions worldwide, as the average life expectancy progress shows. But is also a system whose design draws resources from the peripheries to the center, through well-known mechanisms: to publish in high impact Anglophone journals research must comply with subject and presentation criteria that tend to produce a standardization of publication topics and modalities, ultimately shaping the scientific field, and accentuating inequalities between areas emerging from different research and publishing cultures. Language policies, and language struggles, present in the academic publishing industry, have a considerable impact in this drawing of scientific resources.

The question arises in all non-Anglophone European nations since the EU's foundation. Multilingualism is a European aspiration and the EU official policy (GAZZOLA, 2006; ROMAINE, 
2013). The origins of this policy lie in French being the main communication language in EEC institutions since 1957, something that changed with the joining of the UK in 1973, which brought an imbalance to the existing language landscape. "France responded to the threat of English by promoting European multilingualism" as a way to avoid "a major loss of French presence in Europe and in the world" (PÉREZ et al., 2016). Since then multilingualism is inscribed in the main treatises (LISBON 2007; MAASTRICHT 1992). "Brexit", if occurring, will surely impact this language balance, and amid rumors English might cease to be one of the official languages, it is likely to increase the importance of a multilingual language policy (CARMICHAEL, 2016; GINSBURGH et al., 2017; SNEL, 2017; VÍTORES, 2017).

However, multilingualism is not standard in scientific policy in most European countries, notably Portugal and Spain, which encourage and value publishing in English language venues, even in areas where that may be a disadvantage due to research's local rooting: Humanities, Arts \& Letters and Social Sciences (GRADIM; MORAIS, 2016a).

The recent developments in WoS publication languages this work discloses have emerged despite both countries national scientific and evaluation policies (GRADIM et al., 2014), and reflect the demographic and economic impact of Portuguese and Spanish speaking countries. But they also reflect the diversity and quality of the research accomplished, and ought to be considered not only a national but also a EU asset. German, with its 97 million speakers, has been consistently occupying top places regarding scientific publication language, expressing both the strength of its research and the importance of Germany in the European and world context.

Multilingualism has had strong advocates (PHILLIPSON, 2000; MAR-MOLINERO, 2004; FISHMAN, 2006). We argue for its importance in R\&D activities highlighting three inter-related aspects: lexical construction, thought and cultural construction, and epistemological diversity.

Research done in languages other than English allows for the formation of a technical and scientific lexicon in which that language can express itself. In time, a country that runs all its scientific research in an external language will lose the lexicon proper to the expression of science. An involution of this kind precludes language from fulfilling some of its functional domains (STEWART, 1968) negatively affecting the status and stance of that language. "A language of culture and thinking must be, also, a language of knowledge" says Moisés Martins (2012, 2014), in the sense that thought, culture and civilization cannot thrive in a foreign idiom. When a language ceases to be a vehicle of knowledge, colonization and assimilation are set in motion. 
Finally we argue that one of the tendencies driving technological globalization is the crushing of cultural diversity (HALL, 1991), establishing a center-periphery oriented topology in which, as Bourdieu (1991) or Foucault (1980) have shown, power plays a major role. Science originating in such ecosystems has a definite unique character that overpowers its potential diversity, most notably in Humanities and Social Sciences.

All these processes - lexical, cultural and epistemological construction - are interrelated. Furthermore, power imbalance accentuates for scientists expressing in non-native languages, for whom the current publication and evaluation system is a device propelling English language dominance (FLOWERDEW, 2000; CANAGARAJAH, 2002; CURRY; LILLIS, 2004; ANDERSON, 2013).

There is no denying English is an indispensable vehicular language for scientific communication, but for those in the peripheries its shortcomings and inadequacies must also be owned and remediated.

Science policies that protect language diversity are possible and have been putted in place for some years, mostly in Northern European countries (HILMARSSON-DUNN, 2006; SIVERTSEN, 2010; COSTA, 2015). As our study shows, Spanish and Portuguese as supranational languages (DE SWAAN, 1993) hold the potential to a good performance in the world's communicative, cultural, artistic and scientific markets and local policy makers ought to do more to preserve their status of supranational languages with reference to the "supercentral language" (idem) English is, instead of discouraging it in what concerns R\&D and academic publication (GRADIM; MORAIS 2016b).

\section{CONCLUSIONS}

For all the progress and advances modern science has brought us since the $17^{\text {th }}$ century, its coming together is not natural or given, but the result of a construction and objectification ethos (Latour) whereby knowledge and discourse become power agents (Foucault).

The current scientific and technological apparatus, which includes Academia and the academic publication industry, is also a power-exerting device in which the rise of one language over others, for much as we need it as a vehicle of global communication, serves and perpetuates the inequalities within that system.

In WoS since the sixties, several linguistic trends are evident and some surprising: English language usage has reinforced its influence from $95 \%$ and $93 \%$ in SCI and SSCI, to $97 \%$ and $96 \%$ 
in 2015; while Portuguese and Spanish rose from irrelevance to surpass traditionally strong science languages as Russian, German and French.

Iberian idioms became the second most published language both in SCI and SSCI after 2009, reaching nearly $1 \%$ of the total production, that is, one-third of all non-English output. In addition, and based on inference statistical parameters, we find that in this recent period Iberian languages show significant differences from all other languages (except German, which for now surpasses by a small but consistently growing margin).

Being the world's second language of science is no small feat taking into account that both Spanish and Portuguese science policies actively discourage publishing in LOTE - Languages Other than English - and prize "international" publication, conceived as publication in Anglophone indexed vehicles. The vigor of both languages is an asset to their national native speakers, and certainly could also be considered a EU asset, a valuable element of linguistic capital, understood as "power over the linguistic price formation" and the power to make those laws "operate to one's advantage" extracting value (Bourdieu, 1993); while power itself is taken to be the structural capacity of a social actor to impose his will over others. Institutional systems are a product of power relations, "negotiated by a historical process of domination and counter-domination". Iberian languages' rise in the world scientific publication apparatus might be understood as what Castells (2007) called a counter-power formation process, meaning "the capacity by social actors to challenge and eventually change the power relations institutionalized in society" (p. 248).

Considering an idiom's importance to lexical, thought and epistemological construction, it's all the more surprising to watch Portuguese and Spanish scientific policies assisting the peaceful erosion of this linguistic capital. Linguistic modesty in the face of the exuberant growth of the last decades seems unwise. Advocating multilingualism accepting global English would be a more rational course of action, and, at least until "the end of Babel" (Eco) there are advantages in envisaging language diversity as a tool for its mastery.

\section{REFERENCES}

ANDERSON, L. Publishing strategies of young, highly mobile academics: the question of language in the European context. Language Policy, v. 12, n. 3, p. 273-288, 2013. ISSN 1568-4555.

BOURDIEU, P. Ce que parler veut dire. L'economie des échanges inguistiques. Paris: Fayard, 1982. ISBN 978-2-213-63944-4. 
BOURDIEU, P. Language and symbolic power. Cambridge, Mass.: Harvard University Press, 1991. ix, 302 p. ISBN 0674510402 (alk. paper).

BOURDIEU, P. Sociology in Question. London: Sage, 1993. ISBN 0-8039-8337-9.

CANAGARAJAH, S. Reconstructing local knowledge. Journal of Language, Identity and Education, v. 1, n. 4, p. 243-259, 2002. ISSN 1534-8458.

CARMICHAEL, M. Could English be ousted as an EU official language? Euronews. Lyon, France: Euronews 2016.

CASTELLS, M. Communication, power and counter-power in the network society. International Journal of Communication, v. 1, n. 1, p. 29, 2007. ISSN 1932-8036.

COSTA, J. Scientific Output in Humanities and Social Sciences: Problems and Alternatives. In: GRADIM, A. e MOURA, C. (Ed.). Communicating and Evaluating Science. Covilhã: LabcomBooks, 2015. cap. 3, p.49-58. (Research in Communication). ISBN 978-989-654-238-2. 978-989-654-240-5.

CRYSTAL, D. English as a global language. New York: Cambridge University Press, 2003. ISBN 978-0-511-07862-0.

CURRY, M. J.; LILLIS, T. Multilingual scholars and the imperative to publish in English: Negotiating interests, demands, and rewards. TESOL quarterly, v. 38, n. 4, p. 663-688, 2004. ISSN 1545-7249.

DE SWAAN, A. The emergent world language system: An introduction. International Political Science Review, v. 14, n. 3, p. 219-226, 1993. ISSN 0192-5121.

FISHMAN, J. A. Do not leave your language alone : the hidden status agendas within corpus planning in language policy. Mahwah, N.J.: Lawrence Erlbaum Publishers, 2006. ix, 158 p. ISBN 0805850236.

FLORES, N.; CHAPARR0, S. What counts as language education policy? Developing a materialist Antiracist approach to language activism. Language Policy, p. 1-20, 2017. ISSN 1568-4555.

FLOWERDEW, J. Discourse Community, Legitimate Peripheral Participation, and the NonnativeEnglish-Speaking Scholar. TESOL quarterly, v. 34, n. 1, p. 127-150, 2000. ISSN 1545-7249.

FOUCAULT, M. Power/knowledge : selected interviews and other writings, 1972-1977. Brighton, Sussex: Harvester Press, 1980. xi, 270 p. ISBN 085527557X.

FOUCAULT, M. As palavras e as coisas: uma arqueologia das ciências humanas. Edições 70, 2010.

GARFIELD, E. English-An International language for science. The Information Scientist, Dec, v. 76, p. 19-20, 1967.

GARFIELD, E. Citation Indexing, its Theory and Application in Science, Technology and Humanities. New York: John Wiley and Sons, 1979. ISBN 0-471-02559-3. 
GARFIELD, E. New international professional society signals the maturing of scientometrics and informetrics. The Scientist, v. 9, n. 16, p. 11, 1995.

GARFIELD, E.; KIMBERLEY, R.; PENDLEBURY, D. Mapping the social sciences: the contribution of technology to information retrieval.

Essays of an Information Scientist: Science Literacy, Policy, Evaluation, and other Essays, v. 11, p. 369-374, 1988.

GAZZOLA, M. Managing Multilingualism in the European Union: Language Policy Evaluation for the European Parliament. Language Policy, v. 5, p. 393-417, 2006.

GINSBURGH, V.; MORENO-TERNERO, J.; WEBER, S. Ranking languages in the European Union: Before and after Brexit. European Economic Review, v. 93, p. 139-151, 2017. ISSN 0014-2921.

GRADIM, A.; MORAIS, R. Anões aos ombros de gigantes: desafios contemporâneos na comunicação de ciência. Lisboa, Portugal: Livros Horizonte, 2016a. 200 ISBN [no prelo].

GARFIELD, E. Tendências atuais na publicação científica: o português como língua de ciência. Observatorio (OBS*), v. 10, n. 3, 2016b. ISSN 1646-5954.

GRADIM, A.; SERRA, P.; TELLERÍA, A. "La Evaluación de los Profesores de Educación Superior en Portugal y España”. In: (COORD), C. J. S. M. (Ed.). Didactica Actual para la Enseñanza Superior. Madrid, Espanha: ACCI - Asociación Cultural y Científica Iberoamericana, 2014. cap. XII, p.227-246. ISBN 978-84-15705-26-0.

HALL, S. The Local and the Global: Globalization and Ethnicity. In: KING, A. D. (Ed.). Culture, Globalization and the World-System: contemporary conditions for the representation of identity. New York: Palgrave, 1991. ISBN 978-0-333-53560-8.

HAMEL, R. E. The dominance of English in the international scientific periodical literature and the future of language use in science. AILA Review, v. 20, n. 1, p. 53-71, 2007. ISSN 1570-5595.

HILMARSSON-DUNN, A. M. Protectionist Language Policies in the face of the forces of English. The case of Iceland. Language Policy, v. 5, n. 3, p. 295-314, 2006. ISSN 1568-4555.

JOSEPH, J. E. Language and Politics. Edinburgh: Edinburgh University Press, 2006. ISBN 9780 748624539.

LATOUR, B. Science in action: How to follow scientists and engineers through society. Harvard University Press, 1987. ISBN 0674792912.

MAR-MOLINERO, C. Spanish as a world language: Language and identity in a global era. Spanish in Context, v. 1, n. 1, p. 3-20, 2004. ISSN 1571-0726.

MARTINS, M. L. Revistas científicas de Ciências da Comunicação em Portugal: da divulgação do conhecimento à afirmação do Português como língua de pensamento. Intercom: Revista Brasileira de Ciências da Comunicação, v. 35, n. 1, 2012. 
MARTINS, M. L. Língua Portuguesa, globalização e lusofonia. In: BASTOS, N. (Ed.). Língua Portuguesa e Lusofonia São Paulo: EDUC - IP-PUC, 2014. p.15-33. ISBN 8528304663.

MENEGHINI, R.; PACKER, A. L. Is there science beyond English? EMBO reports, v. 8, n. 2, p. 112116, 2007. ISSN 1469-221X.

OSTLER, N. The last lingua franca: English until the return of Babel. Bloomsbury Publishing USA, 2010. ISBN 0802778704.

PAGE, L. et al. The PageRank citation ranking: Bringing order to the web. Stanford InfoLab, p.17. 1999

PENNYCOOK, A. English, Politics, Ideology: From Colonial Celebration to Postcolonial Performativity. In: RICENTO, T. (Ed.). Ideology, Politics and Language Policies: Focus on English: John Benjamins Publishing Company, 2000. ISBN 90-272-1836-6.

PENNYCOOK, A. The cultural politics of English as an international language. Taylor \& Francis, 2017. ISBN 1351847368.

PÉREZ, A.; LORENZO, F.; PAVÓN, V. European bilingual models beyond linguafranca: key findings from CLIL French programs. Language Policy, v. 15, n. 4, p. 485-504, 2016. ISSN 1568-4555.

PHILLIPSON, R. English in the New World Order: Variations on a Theme of Linguistic Imperialism and "World" English. In: RICENTO, T. (Ed.). Ideology, Politics and Language Policies: Focus on English: John Benjamins Publishing Company, 2000. ISBN 90-272-18366.

PHILLIPSON, R. Linguistic imperialism continued. New York, NY: Routledge, 2009. 288 p. ISBN 9780415872010 (pbk).

RETO, L.; MACHADO, F. L.; ESPERANÇA, J. P. Novo Atlas da Língua Portuguesa. Lisboa: Imprensa Nacional Casa da Moeda, 2016. ISBN 978-972-27-2516-3.

RICENTO, T. Ideology, Politics and Language Policies. In: RICENTO, T. (Ed.). Ideology, Politics and Language Policies: Focus on English: John Benjamins Publishing Company, 2000. ISBN 90-2721836-6.

ROMAINE, S. Politics and policies of promoting multilingualism in the European Union. Language Policy, v. 12, n. 2, p. 115-137, May 2013. ISSN 1568-4555. Disponível em: < <Go to ISI>:// WOS:000320381300001 >.

SIVERTSEN, G. A performance indicator based on complete data for the scientific publication output at research institutions. ISSI newsletter, v. 6, n. 1, p. 22-28, 2010.

SNEL, I. Using English in the EU after Brexit: "If we don't have the UK, we don't have English". Euroculturer: Erasmus Mundus Association 2017.

STEWART, W. Sociolinguistic Typology of Multilingualism. In: FISHMAN, J. (Ed.). Readings in the Sociology of Language. The Hague: Mouton Publishers, 1968. 
TESTA, J. The Thomson Reuters Journal Selection Process. Transnational Corporations Review, v. 1 , n. 4, p. 59-66, 2009/01/01 2009. ISSN 1918-6444. Disponível em: < http://www.tandfonline.com/doi/ abs/10.1080/19186444.2009.11658213 >.

VAN WEIJEN, D. The language of (future) scientific communication. Research Trends, v. 31, p. 7-9, 2012.

VÍTORES, D. F. El español: una lengua viva - informe 2016. Instituto Cervantes. http://www. cervantes.es/imagenes/File/prensa/EspanolLenguaViva16.pdf. 2016

VÍTORES, D. F. Does Brexit spell the end for English as the lingua franca of the EU? LSE European Politics and Policy (EUROPP) Blog, 2017. 